\title{
Improving Students' Descriptive Text Writing by Using Writing in the Here and Now Strategy at the Tenth Grade Students of Vocational High School
}

\author{
Fitriani1 1,a", Rafi Hamdi Nur2,b, Bustamin ${ }^{2, c}$, Syahban Mada Ali2,d, Nurisman²,e \\ ${ }^{1}$ Department of English, Faculty of Teachers Training and Education, STKIP YPUP Makassar, South Sulawesi, 90222, Indonesia \\ 2 Department of English, Faculty of Teachers Training and Education, Universitas Tomakaka Mamuju, West Sulawesi, 91511, Indonesia \\ a fitrianimarsude@gmail.com; b tifahrapie01@gmail.com, c bustamin@gmail.com, d syahban@gmail.com, enurisman@gmail.com \\ ${ }^{*}$ Corresponding Author \\ Whatsapp number: [085395885687]
}

How to Cite : Fitriani, F., Nur, R. H., Bustamin, B., Ali, S., M., Nurisman, N. (2019). Improving Students' Descriptive Text Writing by Using Writing in the Here and Now Strategy at the Tenth Grade Students of Vocational High School. International Journal for Educational and Vocational Studies, 1 (6), $632-636$

\section{ARTICLE HISTORY}

Received: 3 July 2019

Revised: 23 August 2019

Accepted: 10 September 2019

\section{KEYWORDS}

Writing Skills;

Teaching Strategy;

Descriptive text;

\section{ABSTRACT}

The objective of the research is to find out whether or not the use of writing in the here and now strategy improve students' ability in writing descriptive text at class $X$ of SMK Negeri 1 Mamuju. The method of this research was quantitative method and type of this research was pre-experimental with one group pre-test, treatment and post-test design. In this research, the researchers took the tenth grade of the second semester in which the total numbers of the population were 323 , and the samples consist of 37 students. Based on the data analysis, the alternative hypothesis in this research was accepted because t-test value was more significant than $t$-table value $(11.06>1.688)$. The researchers conclude that Writing in Here and Now strategy can improve the Students' Writing Skill at Tenth Grade Students on the second semester of SMK Negeri 1 Mamuju in academic year 2017/2018.

This is an open access article under the CC-BY-SA license.

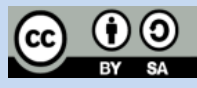

\section{INTRODUCTION}

Writing skill is one of the English skills that are still difficult to master by students. Rass (2001:30) stated, "Writing is a difficult skill for native speakers and non-native speakers; since the writers must be capable composing it in various issues, for example, association, content, reason, vocabularies, and mechanics, for example, spelling, accentuation, and capitalization". It is because there are a few angles that the aspects ought to figure out how to do decent writing. However, the students have to master the writing skill since this skill has consistently been viewed as a significant ability in English language learning (Syarofi, Kuswahono, \& Rizky, 2018).

Writing includes several components of language (content, grammar, vocabulary, and punctuation). Writing skill cannot be mastered in a short time, and it takes training and practice that is not small and continuously. Students are also required to be able to master grammar and vocabulary that could express and communicate ideas in writing.

The purpose of writing activities for students is to be able to express an idea or ideas, opinions, and knowledge possessed in writing. Brown and Abeywickrama (2004) reveal that writing is a process to create some ideas of students' knowledge to be a written report. Writing is not an easy job, and not everyone can write well. Harmer (2007) explains that "writing is a complex cognitive process that sustained intellectual effort over a considerable period".

One of the skills which need to be mastered by the vocational high school students is writing skill, especially a descriptive text. This statement is in line with Noprianto (2017), who stated that descriptive text is one of the text types which is requested to master by secondary schools in Indonesia. However, this type of text is the most difficult for students. Rusmawan (2017) reveals that the most challenging text is the descriptive text. Therefore, teachers should avoid a monotonous way of teaching writing. They should find out a good strategy in teaching writing to make students interest. The teacher should be able to promote successful learning content as a facilitator and maintain the class always enjoyable (Zainuddin, 2015). Writing skills can be created when the 
interests of the learners are recognized, and when they are frequently offered six possibilities to work on writing (Ismail, 2011).

Descriptive text is a kind of texts which is used to describe the real object (person, place, and things). It will help the reader more understand clearly about the real object. Then descriptive text consists of identification and description. Identification is a process of how to an object that wants to describe. Then, the description is a process on how to describe the object. Descriptive text is a sort of text used by every writer or person to explain a thing, individual, animal, location or incident to a reader or listener (Knapp \& Watkins, 2005).

Based on the result of interview with one of the English who were in SMKN 1 Mamuju and based on direct observation how the ability students' writing skill that researcher did during activity, he said that students' writing descriptive text was still very low in the amount of $50 \%$ based on result of assessment to student's task. The students still face difficulty in writing a descriptive text.

This problem arose due to the lack of awareness of the students to improve their writing skill, and writing skill was still said to be lacking in vocabulary, grammar, and to create ideas are still lacking. Most of them write their way without regard to the use of grammar and vocabulary in English, and it was known that the difficulties experienced in writing are the difficulty of finding the ideas to be told in written language. This matter had led to the need to take action to improve the writing skills of students in writing a descriptive text.

Based on the problem above, the researchers were interested in solving problems encountered in the learning process, including the low ability to write in the form of descriptive text. One strategy that can be used as the method of Writing is "here and now" strategy. It is writing strategies experiences directly or in the here and now "(writing in the here and now") is a dramatic way to enhance self-reflection by asking the students to write a report at the time the action is (present tense) on an experience they have (it happened here and now). This activity allows students to think about the experience that they have. Silberman (2009) declares "Writing in the here and now the strategy is a learning strategy that helps learners to reflect on the experiences that they have been through it directly". Furthermore, Silberman (2009) defines Writing in the here and now is a writing lesson by reflecting the experiences that have been experienced (as if the action was happening here and now). By using these methods, the students will be easy to find and develop story ideas.

The previous researchers found that the students got improvement in writing by using Writing in the Here and Now Strategy (Northey et al., 2018; Setyawati, 2016; Siagian, 2016). Additionally, (Northey et al., 2018) conducted a study on "here and now learning" and found that "Here and now" instruction has a beneficial impact on student achievement, behaviour, student engagement and academic achievement.
The students require the recent study focused on the use of "Here and Now strategy "in descriptive writing since the descriptive writing skill, and it is difficult for them. Therefore, an appropriate strategy will help them to master the skill effectively. The objective of the research is to find out whether or not the use of Writing in the here and now strategy improve students' skill in writing a descriptive text.

\section{METHODS}

This research was conducted in SMK Negeri 1 Mamuju, Mamuju district. The researcher's reason to conduct this research in this school based on the result of observation and interview with the teacher that shows there were still many students still less in English, especially in writing. Many of them write using their way without regard to the use of grammar and vocabulary in English and writing in the here and now strategy never used in the school to teaching writing in descriptive text and it relates to the researcher's problem.

\subsection{Research Design}

The research design was a pre-experimental design with one group pre-test and post-test design. It was intended to see how the writing in the Here and Now strategy influences the students' writing descriptive text. The treatment was given between pre-test $(\mathrm{O} 1)$ and post-test (O2). The design is presented as follows.

Notes: $\mathrm{O} 1 \mathrm{X}$
$\mathrm{O} 1=$ pre-test
$\mathrm{X}=$ treatment
$\mathrm{O} 2=$ post-test
(Adapted from Sugiyono, 2000).

\subsection{Population and Sample}

The population of this research was the tenth-grade students of SMK Negeri 1 Mamuju in 2018/2019 Academic Year, which consists of nine classes. Those are divided into five departments. They are two classes of Accounting major, three classes of office administration major, one class of agricultural processing techniques major, two classes of computer and network technique major and one class of electrical technique major. The sampling technique that was used in this research was Purposive Sampling. In which the researcher take one class for experimental class, namely X TPHP, which consists of 37 students. The researcher chose that sample because X.TPHP there were still many students who are still less in English, especially in writing ability.

\subsection{The instrument of the Research}

The instrument of this research was a test. The test was a collection test writing that uses to determine students' ability. This test consists of two tests which the first was pre-test and the second was post-test. The researcher gave the pre-test before giving treatment in the classroom. 
It is aimed to know the students' prior knowledge before giving treatment. The pre-test is a writing paragraph which students write a paragraph with theme" my best friend" based on three instructions and post-test was given after giving treatment to know students' improvement after being given treatment, and the test that was used is the same (pre-test).

\subsection{Statistical Data Analysis}

The data was collected from students' result of the test written questions. The researchers gave this procedure before giving treatment in the classroom. It was aimed to know the students' prior knowledge before giving treatment. The researcher gave pre-test before giving treatment in the classroom. It was aimed to know the students' prior knowledge before students were given treatment. The per-test is a writing paragraph which students write a paragraph with theme" my best friend", and it runs 75 minutes. treatment, and it was conducted for one month. The researcher gave treatment six times. Each meeting, it ran for 90 minutes based on the strategy that is used in this research, namely writing in the Here and Now strategy. After giving the treatment, the researchers conducted post-test. This test is aimed at finding out the students' understanding of writing a descriptive text. The data from the pre-test and post-test were analyzed quantitatively.

\section{RESULTS AND DISCUSSIONS}

\subsection{The Result of Each Component of Writing Pre-Test and Post- Test}

Based on the data from the written test, it can be concluded from the result of pre-test and post-test find out difference each indicator components, and the writing has five components, it consists of content, organization, language use, vocabulary and mechanic. There were the improvements from the component from Pre-Test and Post-Test that showed in the table 1.

After giving pre-test, the researchers conducted

Table 1. Components of Writing in Pre-test and Post-test

\begin{tabular}{clc}
\hline Component & Pre-test & Post-Test \\
\hline Content & $22.71 \mathrm{a}$ & 82 \\
\hline Language Use & $16.50 \mathrm{~b}$ & 87 \\
\hline Organization & $16.47 \mathrm{~b}$ & 90 \\
\hline Vocabulary & $22.33 \mathrm{a}$ & 86 \\
\hline
\end{tabular}

Based on the result of pre-test and post-test, it shows that the students score for content from 19.10 in pre-test to 22.62 in post-test with improved from pre-test to post-test was 3.52 , language use from 12.13 in pre-test to 15.30 in post-test with improved from pre-test to post-test was 3.17 , organization from 14.49 in pre-test to 17.03 in post-test with improved from pre-test to post-test was 2.54 , vocabulary from 10.67 in pre-test to 13 in post-test with improved from pre-test to post-test was 2.33 and mechanics from 2.75 in pre-test to 2.78 in post-test with improved from pre-test to post-test was only 0.03 .
Based on the result above, it could be concluded that after giving treatment, it shows that the result of the post-test is higher than the pre-test. It means that students' writing skill has improved.

\subsection{T-test Value of Students}

The t-test was used to find out the significant difference between the pre-test and post-test. The t-test of the students' that taught by using Writing in the here and now strategy in learning writing is shown through the following table 2 .

Table 2. Components of Writing in Pre-test and Post-test

\begin{tabular}{|c|c|c|c|c|c|c|}
\hline & Variable & \multicolumn{2}{|c|}{ T-test Value } & \multicolumn{3}{|c|}{ T-table Value } \\
\hline \multicolumn{2}{|r|}{$X 2-X 1$} & \multicolumn{2}{|c|}{11.06} & \multicolumn{3}{|c|}{1.688} \\
\hline \multirow[t]{2}{*}{ No } & \multirow[t]{2}{*}{ Classification } & \multirow{2}{*}{ Score } & \multicolumn{2}{|c|}{ Pre-test } & \multicolumn{2}{|c|}{ Post-test } \\
\hline & & & Frequency & Persentage & Frequency & Persentage \\
\hline 1 & Excellent & $96-100$ & 0 & $0 \%$ & 0 & $0 \%$ \\
\hline 2 & Very Good & $86-95$ & 0 & $0 \%$ & 2 & $5.40 \%$ \\
\hline 3 & Good & $76-85$ & 0 & $0 \%$ & 6 & $16.22 \%$ \\
\hline 4 & Fairly Good & $66-75$ & 9 & $24.32 \%$ & 26 & $70.27 \%$ \\
\hline 5 & Fair & $56-65$ & 19 & $51.35 \%$ & 3 & $8.11 \%$ \\
\hline 6 & Poor & $36-45$ & 9 & $24.32 \%$ & 0 & $0 \%$ \\
\hline 7 & Very Poor & $0-35$ & 0 & $0 \%$ & 0 & $0 \%$ \\
\hline & Total Score & & 37 & 100 & 37 & 100 \\
\hline
\end{tabular}

The result of the t-test analysis is 11.06 than t-table value was 1.688 . It shows that the t-test value is greater than the t-table value $(11.06>1.688)$. The degree of freedom (df) was 36 (n-1 or 37 1=36), the level of significant $(p)=0.05$, the t-test value $=11.06$ and the t-table value $=1.688$. The t-test value is greater than the 
t-table value $(11.06>1.688)$, it means that the Alternative Hypothesis (H1) was accepted and the Null Hypothesis (H0) was rejected. In other words, there is a significant difference in students' writing skill in pre-test and post-test.

Based on the table above shows the result of pre-test and post-a test that for very poor classification in pre-test is no one students and in post-test is no one students got very poor. For poor classification is $9(24.32 \%)$ in pre-test but in post-test was no one students got poor classification, it means that students' writing skill has improved because there are no one students got poor classification in post-test. For fair classification is $19(51.35 \%)$ in pre-test but post-test is $3(8.11 \%)$. In other word, students writing skill has improved because there are only $3(8.11 \%)$ students got fair classification in post-test. Meanwhile, for fairly good classification is $9(24.32 \%)$ but $26(70.27 \%)$ in post-test, it means that students writing skill have improved because the dominant classification is fairly good in post-test than pre-test. For good classification is no one students in pre-test but post-test is $6(16.22 \%)$, it means that students writing skill have improved because the dominant classification is good classification in post-test and but in pre-test are no one students in good classification. For very good classification is no one students in pre-test but post-test is $2(5.40 \%)$. Therefore, students writing skill has improved because dominant classification is very good classification in post-test. For excellent classification is no one student in the pre-test and no one students got excellent in post-test.

It could be concluded that the rated frequency and percentage the students' post-test was higher than pre-test because the dominant classification in pre-test is $9(24.32 \%)$ students in fair classification and 19 (51.35\%) students in poor classification before giving treatment, and the dominant classification in post-test is $26(70.27 \%)$ students in fairly good, $6(16.22 \%)$ students in good classification and $2(5.40 \%)$ students in very good after giving treatment. It can be concluded that that students' writing skill has improved after being given treatment by using writing in the here and now strategy.

\subsection{Analysis Hypothesis Testing}

As it is explained, finding in the previous chapter that the value of the t-test is more significant than $t$ - table (11.06 > 1.688). It means that the Alternative Hypothesis (H1) was accepted while the Null Hypothesis (H0) was rejected. In other words, there is a significant difference in students' writing skill in pre-test and post-test. The finding informs that the t-test value was higher than t-table value or the students' achievement improves significantly, and the majority of students gets the satisfy value after being given treatment. Hence, it can be concluded that Writing in the here and now strategy can improve the students' skill in writing descriptive text at the tenth grade of SMK Negeri 1 Mamuju.

\subsection{DISCUSSION}

Writing skill is the main focus in this research because students' writing skill in SMK Negeri 1 Mamuju was still low. So the researcher applied writing in the here and now strategy to improve the students' writing skill. This research found that Writing in the here and now strategy can improve the students' skill in writing descriptive text at the tenth grade of SMK Negeri 1 Mamuju.

This research result is in line with the research conducted by (Mukaromah, 2013). She found that writing in the here and now strategy can improve students' vocabulary, motivation, and cheerfulness to write in English and the improvement of the students' writing skill. This research result is also supported by Widayanti (2012). She found the findings in the reasons for implementation, advantages, and disadvantages of writing in the here and now strategy. Besides those two researchers, Northey et al. (2018) found that the beneficial impacts of "here and now" instruction are shown in the incredibly high level of academic results and enhanced student involvement. Therefore, the researchers had concluded that there was a correlation between the present study and some previous studies. The present study has, succeed in applying writing in the here and now strategy.

According to Silberman (2009) the core writing in the here and now strategy is the strategy that can help the students to train and sharpen the imagination of students, enhancing students' creativity, improving students' ability in writing, increasing students' understanding of the core message of the subject matter, and connecting the subject matter with the realities of life.

Based on Silberman (2009) theory, the researchers relate their finding to the participation of students, the activeness of students, the anxiety of students and the interest of students. Participation of students in the learning process showed that after implementing this strategy, the students are active in answering the teacher's questions, giving Feedback and point ideas and the most important thing is that they are creative in concluding. After implementing this strategy, the students are more active. It can be seen when the students' activity and attention during the action, the researchers could see that most of the students are enthusiastic in the teaching-learning process. They could practice language optimally, especially in writing and express their idea through writing directly, even though there were many limited vocabularies and error grammatical. Additionally, they could express their idea, increased their vocabulary and wrote their idea directly.

Additionally, after implementing this strategy, the anxiety of students has an insignificant decrease. Before using this strategy, they are difficult to translate and comprehend the test given because they are lack of vocabulary, so they feel confused to begin writing. Lack of vocabulary becomes a crucial problem in this learning, and they do not bring a dictionary. The interest of students before and after the researcher implementing this strategy is very different. The students are more interested in giving 
opinion or idea to express their writing skill, working on a question in front of the class, and some students focus attention on the material. Therefore, students did not bore in attending the learning process.

\section{CONCLUSION}

Based on the data analysis and discussion, Based on the result above, the researchers could be concluded that applying writing in the here and now strategy be able to improve students' writing skill. Furthermore, the researcher could conclude that the use of writing in the here and now strategy had been successful in improving students' writing skill.

\section{REFERENCES}

Brown, H. D., \& Abeywickrama, P. (2004). Language assessment. Principles and Classroom Practices. White Plains, NY: Pearson Education.

Harmer, J. (2007). The practice of English language teaching. Harlow: Pearson Longman,.

Ismail, S. A. A. (2011). Exploring Students' Perceptions of ESL Writing. English Language Teaching, 4(2), 73-83.

Knapp, P., \& Watkins, M. (2005). Genre, text, grammar: Technologies for teaching and assessing writing. UNSW Press.

Mukaromah, N. (2013). The Use of "Writing in the Here and Now" Strategy To Improve Students'writing Ability (A Classroom Action Research of the First Grade Students of SMP Nusantara Tuntang Semarang in the Academic Year of 2012/2013). Skripsi.

Noprianto, E. (2017). Student's Descriptive Text Writing In SFL Perspectives. IJELTAL (Indonesian Journal of English Language Teaching and Applied Linguistics), 2(1), 65-81. doi: 10.21093/ijeltal.v2i1.53

Northey, G., Govind, R., Bucic, T., Chylinski, M., Dolan, R., \& van Esch, P. (2018). The effect of "here and now" learning on student engagement and academic achievement: Mobile collaboration and student engagement. British Journal of Educational Technology, 49(2), 321-333. doi: 10.1111/bjet.12589

Rass, R. A. (2001). Integrating reading and writing for effective language teaching. English Teaching Forum, 39, 1-5.

Rusmawan, P. N. (2017). Genre based Approach to Teach Writing Descriptive Text. JEES (Journal of English Educators Society), 2(2), 119-134. doi: 10.21070/jees.v2i2.875

Setyawati, H. (2016). The Use Of Writing "In The Here And Now"Strategy To Improve Students' Writing Ability At The Tenth Grade Of Smk Darul Fikri Bringin Kauman Ponorogo In The Academic Year Of 2015/2016 (Skripsi, Universitas Muhammadiyah Ponorogo). Retrieved from https://library.umpo.ac.id

Siagian, S. (2016). The Use of "Writing in the Here and Now" Strategy in Improving Students' Writing Skills to the Tenth Grade Students of SMK S Kampus Padangsidimpuan in 2015 - 2016 Academic Year. Jurnal Estupro, 1(1), 10-19.

Silberman, M. (2009). Active learning: 101 strategi pembelajaran aktif. Yogyakarta: Pustaka Insan Madani.

Sugiyono, D. R. (2000). Metode Penelitian. Bandung: CV Alvabeta. Retrieved from http://digilib.unila.ac.id/6579/17/BAB\%20III.pdf

Syarofi, A., Kuswahono, D., \& Rizky, H. (2018). Implementing Process Writing Strategy Using Weblogs to Improve Students' Ability in Writing Descriptive Text. Lingua Cultura, 12(4), 351-355. doi: 10.21512/lc.v12i4.4142

Widayanti, E. (2012). Pembelajaran Menulis Kreatif Puisi Dengan Menggunakan Strategi Writing In the Here and Now. STKIP Siliwangi, Bandung.

Zainuddin, Z. (2015). The Effect of Cooperative Integrated Reading and Composition Technique on Students' Reading Descriptive Text Achievement. English Language Teaching, 8(5), p11. doi: 10.5539/elt.v8n5p11 